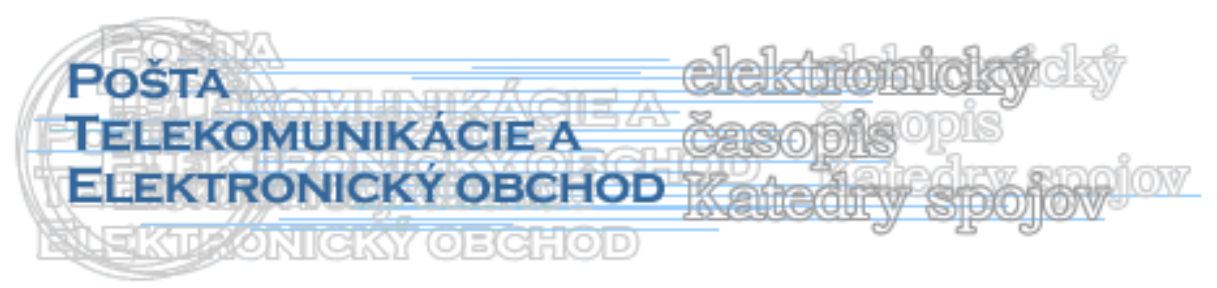

\title{
NOVÉ SLUŽBY PORTÁLU VEREJNEJ SPRÁVY
}

\author{
Margita Majerčáková ${ }^{1}$, Radoslav Holka ${ }^{2}$
}

\section{Úvod}

Portál verejnej správy si možno predstavit' ako akýkol'vek informačný systém poskytujúci systematicky utriedené a vzájomne prepojené informácie o jednotlivých subjektoch, ich činnostiach a výsledkoch ich činnosti. V oblasti vládnych orgánov dnes existujú samostatné servery jednotlivých štátnych orgánov, prípadne Úradu vlády, pričom tieto servery obsahujú väzby a prepojenia také, že sa v určitej oblasti i tieto servery chovajú ako portály. Portál verejnej správy by mal obsahovat' všetky dostupné informácie o organizáciách, orgánoch a činnosti verejnej správy, kontrole verejnej správy a právnych normách s verejnou správou súvisiacich.

\section{1 Účel portálu verejnej správy}

Účelom portálu je:

- poskytovat' fyzickým a právnickým osobám vzdialený prístup ku kompletným informáciám a službám jednotlivých inštitúcií verejnej správy,

- sprístupnit' celej verejnej správe jej znalosti, fakty a záznamy,

- zvýšit' efektivitu a autoritu verejnej správy,

- posilnit' dôveru občanov smerom k verejnej správe,

- umožnit’ štátnej správe vystupovat’ ako integrálna organizácia.

\section{Nové služby portálu verejnej správy}

$\mathrm{Z}$ dôvodu plnej funkčnosti portálu verejnej správy je potrebné úplne zavedenie personalizovaných služieb. Prostredníctvom presonalizovaných služieb priamo na mieru bude možné spracovávat' individuálne elektronické účty o občanoch, podnikatel'och a firmách, na ktorých bude môct' klient prostredníctvom účtu na ústrednom portály verejnej správy sledovat' všetky svoje elektronické transakcie a údaje o sebe. Verejná správa bude v integrovanom informačnom systéme aktualizovat' údaje o občanoch, podnikatel'och a firmách len raz s tým, že aktualizácia prebehne automaticky vo všetkých informačných účtoch, t.j. zavádzanie centrálneho registra. Účty budú rešpektovat' rôznorodost' l'udí, ktorí vstupujú do vzt'ahov s verejnou správou. Každý občan si bude schopný vytvorit' personalizovaný pohl'ad, ktorý ho upozorní na najdôležitejšie služby a informácie týkajúce sa jeho potrieb. Pre každého občana či podnikatel'a sa zavedie jedinečný účet na prístup k službám verejnej správy cez preferovaný kanál.

\footnotetext{
1 * Dr. Ing. Margita Majerčáková, Katedra spojov, Fakulta prevádzky a ekonomiky dopravy a spojov, Žilinská univerzita v Žiline, Univerzitná 1, 01026 Žilina, Slovenská republika, tel.: +421415133126, fax: +421415655615 e-mail: Margita.Majercakova@fpedas.uniza.sk

${ }^{2}$ Ing. Radoslav Holka, Hronské Kl'ačany 10, 935 29,Hronské Kl’ačany,Slovenská republika, tel: +421903946052 e-mail: radoslav.holka@gmail.com
} 
Popri typických službách poskytovaných verejnou správou ako napr. registrácie, dane, clá, vol'by budú samosprávy občanom ponúkat' rôzne služby ako odpoved' na široký stupeň každodenných životných situácií. Poskytovanie špecifických služieb verejnej správy sa presunie skôr na lokálnu ako na centrálnu úroveň. Toto môže byt' prípad agend, ktoré realizujú samosprávy na základe prenesených kompetencií, ako napríklad matrika, evidencia pobytu, stavebné konanie, ochrana životného prostredia alebo agend vyplývajúcich z originálnych kompetencií samospráv ako napríklad: miestne dane a poplatky, sociálna starostlivost'. Zvyšovanie elektoronizácie služieb verejnej správy a ich presun do územnej samosprávy povedie $k$ lepšej pripravenosti informačnej spoločnosti a $k$ zvyšovaniu konkurencieschopnosti krajiny na globálnej úrovni.

Ako d’alšia služba by sa dala spomenút' SMS notifikácia občanom o blížiacom sa konci platnosti ich cestovného pasu alebo občianskeho preukazu.

\section{Predpoklad pre zavedenie transakčných služieb}

Slovensko je úplne na konci rebríčka krajín poskytujúcich pro-aktívne alebo transakčné služby. Problémom je chýbajúca elektronická identifikácia občanov/podnikatel’ov. Tento problém by riešila možnost' zavedenie elektronických identifikačných preukazov, e-ID preukazov.

Elektronická identifikačná karta, alebo preukaz, by okrem svojej pôvodnej funkcie, ktorá je a bude identifikácia občanov bude mat'v sebe zabudovaný elektronický čip.

Úlohou takejto integrovanej karty bude:

- vizuálny identifikátor svojho držitel'a,

- identifikácia držitel'a podl’a biometrických údajov,

- bude obsahovat' elektronický podpis a prostredníctvom príslušnej čítačky. dokáže digitálne podpísat' akýkol'vek dokument či e-mail,

- použitie vo styku so všetkými orgánmi verejnej správy.

Pre zavedenie e-ID je potrebné vytvorit' predpoklady pre ich použitie. Základom elektronického preukazu je čip. Aby sa dal čip použivat' na účel pre ktorý je určený, je dôležitá jeho prvotná inicializácia a personalizácia spočívajúca vo vytvorení požadovaného profilu, z hl'adiska vnútornej súborovej štruktúry.

Hlavnou úlohou je skvalitnenie e-Governmentu na Slovensku a doplnenie transakčných služieb.

\section{4 Štruktúra portálu verejnej správy}

V súčasnosti ma štruktúra portálu verejnej správy hlavné členenie, kde sa používatel' sám rozhoduje, či chce do systému vstúpit' ako občan alebo podnikatel' a na tomto základe využívat' ponúknuté služby. Navrhované členenie by malo začínat' v zmysle sekcií:

- informačná sekcia - model životných situácií, adresár verejnej správy a e-mailov, elektronických podatel'ní atd',, platné znenie zákonov, legislatíva EÚ, náhl'ad do katastra nehnutel'ností,

- transakčná sekcia - e-dane, agenda Ministerstva práce, sociálnych vecí a rodiny, štatistického úradu, ministerstva pôdohospodárstva.

Jednotlivé sekcie, teda informačná a transakčná sekcia sa d’alej členia podl'a služieb, ktoré budú poskytovat'.

1. Informačná sekcia:
a) novinky z verejnej správy a povinne zverejňované informácie,
b) adresár úradov,
c) životné situácie,
d) zákony,
e) verejné obstarávanie, 
f) obchodný register,

2. Transakčná sekcia:

a) elektronické podanie.

\section{1 Informačná sekcia}

Portál verejnej správy bude poskytovat' nasledovné služby podl’a predchádzajúceho členenia.

Novinky z verejnej správy a povinne zverejňované informácie

V tejto sekcii by boli zverejňované:

- na úvodnej stránke zverejňované tlačové správy z ministerstiev a iných úradov a taktiež povinne zverejňované informácie štátnej správy a samosprávy. Tieto správy budú ukladané do archívu, v ktorom bude možné vyhl'adávat' podl'a zdroja, dátumu vydania a taktiež fulltextovo,

- nové zákony spolu s dátumom, ku ktorému vstupujú do platnosti. Každý zákon by bol stručne charakterizovaný tak, aby občan mal prehl'ad o danom zákone a zároveň by obsahoval ak aktívny odkaz na plné znenie zákona,

- zverejňovanie dôležitých dátumov, ako napr. odovzdanie daňového priznania atd'..

Adresár úradov

- adresár bude obsahovat' kontakty na orgány štátnej správy a samosprávy. Okrem fulltextového vyhl'adávania ponúka vyhl'adávanie podl'a regiónov a podl'a druhov úradov. Úrady sú zoradené podl'a sídla $\mathrm{v}$ danom kraji, d’alej okrese, v obciach $\mathrm{s}$ rozšrírenou pôsobnost'ou. Informácie o jednotlivých úradoch a ich činnosti budú prepojené s popisom služieb poskytovaných verejnými orgánmi pre danú obec a ostatné kontaktné údaje a vo väčšine prípadov aj úradné hodiny,

- vyhl'adávanie dostupných úradov štátnej správy a samosprávy bude umožnené prostredníctvom zadania PSĆ, či miesta bydliska.

\section{Životné situácie}

- Sekcia životné situácie bude spracovaná v spolupráci s jednotlivými rezortmi, ktoré sú za príslušné časti zodpovedné. Užívatel' sa dozvie, ktoré doklady potrebuje na vybavenie potrebnej záležitosti, kde, s kým, kedy a čo môže riešit', pol’a ktorých právnych predpisov je potrebné postupovat'. V spolupráci so zástupcami Združenia miest a obcí Slovenska sú na portály uverejnené vzory životných situácií samosprávy. Takto vyplnené životné situácie budú automaticky prepojené na databázu Adresár úradov, Zákony, prípadne Podanie. Strom životných situácií je rozdelený podl’a troch základných skupín užívatel'ov a to pre občanov, podnikatel'ov a pre cudzincov.

\section{Zákony}

- čast' zákony bude poskytovat' bezplatné informácie o platných predpisoch zo Zbierky zákonov v ich aktuálnom znení. Informácie sa budú priebežne aktualizované v deň zverejnenia nového predpisu v Zbierke zákonov. Vyhl'adávat' bude je možné podl'a pojmu v názve zákona, čísla zákona, časti Zbierky zákonov a fulltextovo. Pre lepšiu a rýchlejšiu orientáciu budú hlavné a najčastejšie používané predpisy v samostatnom odkaze - vybrané predpisy. Súčast'ou tejto sekcie bude aj zmluva o pristúpení SR k EÚ a smernice EÚ.

\section{Obchodný vestnik}

- obchodný vestník bude uverejňovat' informácie o zmenách v Obchodnom registri, o konkurzoch, likvidácii podnikov a d'alších informáciách a umožňovat' vyhl'adávanie podl'a obchodného mena, identifikačného čísla, sídla firmy.

Verejné obstarávanie

- prostredníctvom portálu verejnej správy bude zaistený prístup do informačného systému zákaziek verejného obstarávania. 


\section{2 Transakčná sekcia}

\section{Elektronické podanie}

- sekcia elektronické podanie bude poskytovat' služby verejnej správy, ktoré bude možné s využitím elektronického podpisu alebo e-ID vybavit' prostredníctvom portálu verejnej správy. Úlohou je, aby všetky základné služby boli dostupné prostredníctvom portálu verejnej správy.

\section{Záver}

Ústredný portál verejnej správy v súčasnosti transakčnú sekciu ani transakčné služby neponúka. Navrhnuté služby sú však podmienené existenciou elektronickej identifikácie občanov, tzv. e-ID. Vd'aka týmto službám bude možné podávat' daňové priznania, platenie daní, žiadat' o vydanie cestovného pasu, občianskeho preukazu a využívat' mnohé iné služby, ktoré moderný e-Government prináša a prinesie.

\section{Literatúra}

[1] Velešic, M. 2007. e-Government na Slovensku - opät' nový štart? [Online]. [s.a.].[Citované 2008-12-1] Dostupné na: http://www.ivo.sk/buxus/docs/publicistika/subor/eGovernment Infoware.pdf)

[2] Holka, R.: e-Government v SR, diplomová práca, Katedra spojov, 2008

[3] http://portal.gov.sk/Portal/sk/Default.aspx

\section{Grantová podpora}

- VEGA 1/0468/08 Inovačné stratégie v sektore služieb 